\title{
XVII ЗУУНЫ ОЙРАД МОНГОЛЧУУДЫН ТАНГАРГИЙН ЗАН ҮЙЛ
}

Н.Баяриุэиээ ${ }^{1}$

${ }^{1}$ Монгол Улсын Боловсрольнн Их Сургууль Цахим шуудан: o_erdeneus@yahoo.com

Хураангуй: This article dealing with the oath custums of oirat mongols of the 17th century in their relationship with Russian Tsar'. According to detailed analysis of written sources we could unveil two layers of oarh customs : 1) more traditional related to the shamanistic rites, such as cutting the dog, licking the edge of knife or hole gauge; 2) newly coming rites related with the Buddism, like to pray to Buddha.

Түлхуур үг: XVII зуун, ойрадууд, тангаргийн зан үйл

\section{УДИРТГАЛ}

XVII зууны эхэнд Төв Азийн олон улсын нөхцөл байдал өөрчлөгдөж, Орос, Манж гэсэн улсууд хүчирхэгжин гарч ирж, газар нутгийн түрэмгий бодлого явуулах болов. Тэр үед Монгол улс Өвөр Монгол, Халх Монгол, Ойрад гэсэн гурван том хэсэгт хуваагдан оршиж, тус тусдаа бие даан гадаад бодлого явуулах болжээ. Өвөр Монголын ноёд Манжийн төрд дагаар орох, дайсагнасан, найрамдсан зэрэг олон хэлбэрээр харилцаж байв. Монголын баруун талд байсан ойрадууд Орос улстай хэрхэн харилцаж байсан нь бидний анхаарлыг татна. Өгүүлэн буй үеийн Ойрад-Оросын харилцааны нэг онцлог бол Ойрадын ноёдын элч нар Москва болон Сибирийн хотуудад Оросын хаанд “үнэнч байх" тангараг өргөж байсан явдал юм. Тэрхүу тангаргийг Ойрадын ноёдоос Оросын хаанд дагаар орж, чин үнэнчээр зүтгэх тангараг хэмээн шууд ойлгох нь буруу юм. Ойрадуудын хувьд тангаргийг ихэвчлэн тэр үеийн маргаантай асуудлыг шийдэх зорилгоор өргөж байсан билээ. Иймд тангараг нь Ойрадын тайш, ноёдын жинхэнэ зорилгын дипломат халхавч байсан юм. ${ }^{1}$

Монголын түүхийн судалгаанд XVII зууны эхэнд Өвөр Монголын ноёд Манжийн хаанд үнэнч байх тангараг өргөснийг түлхүү бичиж ирсэн байдаг. Өвөр Монголын ноёдоос Манжийн хаанд ямар зорилго, ямар зан үйлээр тангараг өргөсөн нь хэдийнээ тодорхой болсон зүйл юм. Харин Монголын баруун талд хүчирхэгжин гарч ирсэн Орос улсад ойрадууд болон хотгойдууд хэрхэн тангараг өргөж байсан талаар Монголын түүх судлалд төдийлөн хөндөн авч үзээгүй байна. Энэ нь Монголын түYх судлалд XVII зууны эхэн үеийн ОйрадОросын харилцааны түүх харьцангуй бага судлагдсан байсантай холбоотой болов уу. Ойрад-Оросын харилцаан дахь тангаргийн зан үйлийг тодруулан судлах нь Ойрадын

1. В.Т.Тепкеев. Калмыки в Северном Прикаспии во второй трети ХVII века. - Элиста, 2012, с. 45. 
ноёдоос Оросод өргөж байсан тангаргийн зорилго, цаад мөн чанарыг тодорхойлоход ач холбогдолтой юм.

Энэхүү өгүүлэлд орос болон тод бичгийн сурвалжид тулгуурлан ойрадуудын Орос улсад өргөж байсан тангаргийн зан үйлийг тодруулахыг оролдлоо.

\section{Ойрадын тангараг}

Ойрадуудын Оросын “хаанд өргөж байсан” тангаргийн зан үйл А.Г.Митиров, М.Ходарковский, В.Т.Тепкеев нарын бүтээлд товч дурдагдсан байдаг.

Орос улсын түрэмгий бодлогыг зогсоох, түүнтэй улс төр, эдийн засгийн найрсаг харилцаа тогтоох зорилгоор Ойрадын ноёд “Оросын хаанд үнэнч зүтгэх тангараг өрге” гэсэн Оросын түрэмгий шаардлагыг хүлээн авахад хүрчээ. Ингэхдээ Ойрадын ноёд өөрсдийн биеэр бус өөрсдийн элч, ойрын хүмүүсээр Сибирийн хотуудад тангараг өргүүлж байсан онцлогтой.

Орос сурвалжийн мэдээг задлан шинжлэхэд бидэнд мэдэгдэж буй ойрадуудын тангаргийн зан үйлийн талаар 3 янзын мэдээ байна. Эдгээр нь:

1. 1621 онд Москвад Хошуудын Байбагас ханы элч ойрадуудыг “хутга долоож, сум толгойдоо, дараа нь зүрхэндээ тавьж тангарагладаг" г гэж мэдэгдэж байжээ.

2. Үүнтэй бага зэрэг төстэй зан үйлээр 1631 онд Торгуудын Хо өрлөгийн элч Уфа хотод “шар нохой зүсэж, сэлэм ба бууны хоорондуур явж, хурц иртэй хутга долоож” тангараг өргөжээ. ${ }^{3}$

3. 1650-1670-аад онд торгуудууд “нохой зүсэж, цахиур бууны хоорондуур явж, өөртөө авч явсан ариун ном, бурханд мөргөх”, мөн “бурханд мөргөөд судар эрхи үнсч, хутга долоож, хоолойдоо хүргэх, эсвэл хутга, сэлмийг нүүр, хүзүҮ болон толгойдоо тавьж” тангараг өргөж байжээ. ${ }^{4}$

1621 оноос өмнө Ойрадын ноёд өөрсдийн элчээр Сибирийн хотуудад тангараг өргүүлсэн байх боловч чухам ямар зан үйл үйлдсэн нь тодорхой бус юм. Орос сурвалжид ойрадуудын тангараг өргөснийг “өөрийн ёсоор”, эсвэл “өөрийн бус ёсоор” тангараг өргөсөн гэж тэмдэглэснээс өөр зүйл үгүй юм.

Дээрх мэдээнүудийг задлан шинжилвэл ойрадууд Орос улсад дараах хоёр хэлбэрээр тангараг өргөж байжээ. Үүнд:

1. Нохой зүсэх, хутга, бууны ам долоох, сэлэм ба бууны хоорондуур гарах бөөгийн ёсны үлдэгдэл бүхий зан үйл,

2. Бурханд мөргөх зан үйл юм.

Энэ 2 хэлбэрийн зан үйлийн талаар товч авч үзье. 1631 онд Торгуудын Хо өрлөгийн элч Уфа хотод “шар нохой зүсэж” тангараг өргөсөн талаар дээр нэгэнтээ өгүүлсөн билээ. Бүр ХІІІ зуунд монголчууд нохой алж андгай тангараг өргөж байсан талаар Рашидад-Дины “Судрын чуулган”-д тэмдэглэжээ. Уг сурвалжийн мэдээгээр дөрвөн, татар, хонгирад нар азарга, бух, эр нохой алж андгайлсан байна. ${ }^{5}$ Энд нохойны хүйсийг тэмдэглэсэн ба харин зүсийг дурдаагүй байна. Үүнээс үзвэл, нохой алж андгайлах ёс эртний уламжлалтай болох нь тодорхой байна. Ийнхүу тангараглах ёсонд нохой хэрэглэж байсан нь монголчуудын тотем шүтлэг буюу нохой шүтлэгтэй холбоотой. ТийнхүҮ нохойг андгай тангаргийн ёсонд хэрэглэж байсан нь нохой эзэндээ үнэнч байдгийг харгалзан үзсэн хэрэг болов уу.

“Нохой зүсэж” тангараг өргөх зан үйлээр зөвхөн ойрадууд тангараглаж байсангүй, бас өмнөд Сибирийн зарим овог, аймгууд

2. Международные отношения в Центральной Азии ХVII-XVIII вв. Документы и материаль. Сост. Б.П.Гуревич, В.А.Моисеев. Отв. ред. Б.П.Гуревич, Г.Ф.Ким. Книга 1. - М., 1989, с. 54-55.

3. В.Т.Тепкеев. Калмыки в Северном Прикаспии во второй трети XVII века. - Элиста, 2012, с. 44.

4. В.Т.Тепкеев. Калмыки в Северном Прикаспии во второй трети ХVII века. - Элиста, 2012, с. 206; Торгууд хаадын тууж. - Ойрад түҮхэн сурвалж бичиг. Эмхтгэн тайлбарласан Бадай, Алтан-Оргил, Эрдэнэ. Хөххот: Өвөр Монголын соёлын хэвлэлийн хороо, 1985, m. 334; А.Г.Митиров. Договоры, присяги и баранта. - Обычай и обряды Монгольских народов. - Элиста, 1989, с. 64.

5. Рашид-ад-Дин. Сборник летописей. Т.1. - М., 1952, с. 117. 
Үүнтэй төстэй зан үйлээр Оросын хаанд үнэнч байх тангараг өргөж байсан нь орос сурвалжид тэмдэглэгдэн үлджээ. Гэхдээ бага зэргийн ялгаа байна. Тухайлбал, Енисейн Кыргызийн ноён “нохой алж, цусыг нь ууж” тангараг өргөжээ. ${ }^{6}$ Үүнийг С.В.Бахрушин эртний түрэгүүдийн нохой шүтлэг (тотем)-ийн өвөрмөц үлдэгдэл гэж үзжээ. $^{7}$

Орос сурвалжийн мэдээгээр Сибирийн хотуудад тангараг өргөсөн Ойрадын элч нар шар нохой алж тангараг өргөжээ. “Шар нохой” хэмээх хэллэг МНТ-нд нэгэнтээ дурдагддаг билээ. Тэрхүу “шар нохой”-ны бэлэгдэл зүй, домог зүйн агуулгыг зарим судлаач судалж, энэ нь монголчуудын эртний сүлд онгон болох чонын эерүүлэн цээрлэж нэрлэсэн нэр хэмээн үздэг. ${ }^{8}$

Нохой зүсэж цус гаргаж буй нь цусаар андгайлдаг ёсны үлдэгдэл юм. "Цус" гэдэг ойлголтын цаана “хүний амь насны талаарх" ойлголтыг салшгүй холбоотойгоор гаргаж ирж буй ажээ. ${ }^{9}$ ИйнхүY амьтан алж, нэгэн зорилгын төлөө тангараг өргөж ирсэн ёсыг XVII зуунд ойрадуудын хувьд хөрш зэргэлдээх улсад тангараг өргөхдөө болон Сибирийн овог аймгуудаар тангараг өргүүлэхдээ уламжлан авч хэрэглэж байв. Дээрхээс үзвэл ойрадууд болон Енисейн Кыргызийн дотор “нохой” алж, цус гаргаж буй зэргээс үзвэл энэ нь нүүдэлчдийн дунд түгээмэл дэлгэрсэн зан үйл байсан бололтой. Нохой алж тангараг өргөх зан үйл дурдан буй үеийн олон улсын харилцаанд, Ойрад-Оросын, Ойрад-Кыргызийн, ОросКыргызийн харилцаанд өргөн дэлгэрсэн зүйл байсан нь тодорхой байна.

Үүнээс гадна бууны ам долоох ёс хожим хүртэл хэрэглэж байсан талаар нэгэн мэдээ буй. XX зууны эхэнд ЗүҮн Хүрээний бүлгэмийн удирдагч С.Данзан өөрийн бүлгэмийн зарим гишүүдийг бууны ам долоолгож тангараг өргүүж байжээ. ${ }^{10} \mathrm{Mөн}$ сэлэм долоож үнэнч байхын тангараг өргөж байсан талаар Жангар, Бум-Эрдэнэ зэрэг туулиудад үлджээ. Үүнээс үзвэл хутга, сэлэм, буу долоох ёс нь монголчуудын уламжлалт ёс бололтой.

1650-иад оноос Ижилийн торгуудууд дээрх бөөгийн уламжлалт зан үйлийг бурхны шашны зан үйлтэй хослуулан тангараг өргөж байсныг орос сурвалжийн мэдээ илтгэнэ. Энэ нь ойрадуудын тангараг өргөх ёсонд бурхны шашны нөлөө туссаныг харуулж байна.

Бурхны шашны зан үйлээр ойрадууд дотроо тангараг өргөж байсныг тод бичгийн сурвалжид тэмдэглэжээ. Бүр 1610-аад онд Ойрадын ноёд “Шагжамунийн шүтээн, номын сахиус, эрлэгийн цалам барьж, өөрийн бие дээр үрийн үрийн үр уг хүртэл муу үг хэлж, нийтээр андгай” тангараг өргөжээ. ${ }^{11}$ Үүнээс үзвэл ойрадуудын тангараг өргөх ёсонд бурхны шашны нөлөө бүр 1610-аад оноос, тэр дундаа Ойрадад бурхны шашин дэлгэрсэн үеэс нэвтэрсэн бололтой. Энэ тангараг бол ноёд дотооддоо, бие биенийхээ өмнө өргөсөн тангараг гэдгийг тэмдэглэх нь зүйтэй. Ямар асуудал хэлэлцэж, ямар нөхцөлд ийм тангараг өргөсөн нь тодорхой бус байна. Харин 1620-1630-аад онд ойрадууд Орос улсад уг бурхны шашны зан үйлээр тангараг өргөж байсангүй, харин бөөгийн уламжлалт ёсоор тангараг өргөж байсныг өмнө дурдсан билээ.

6. В.Я.Бутанаев, А.Абдыкалькков. Материаль по истории Хакасии ХVII-ХVIII вв. - Абакан, 1995, с. 84.

7. С.В. Бахрушин. Енисейские киргизы в ХVII в. - Научные труды III. Избранные работы по истории Сибири XVI-XVII вв. Ч. 2. История пародов Сибири в XVI- XVII вв. М., 1955, с. 184.

8. С.Дулам. Дархад бөөгийн уламжлал. - УБ., 1992, m. 64; У.Эрдэнэбат. Монгольын Нууи Товчооны Алангоа эхийн домгийн учир. - УБ., 1997, m. 53-54; Б.Бадма-Оюу. Монголчуудын тотем иүтлэг. - Stиdia Ethnologica. T. ХХІV, - УБ., 2016, m. 114.

9. Л.Ганбат. Монголчуудын андгай-тангаргийн ёс, түҮний улс төрийн харилцаанд гүйщэтгэсэн ҮҮрэг. ТҮҮхийн судлал. Т. ХХХVI. - УБ., 2006, m. 78 .

10. Үндэсний төв архив. Ф.23. Д 2. ХН. 17.

11. Гаваншарав. Дөрвөн Ойрадын түҮх. - Ойрад түүхэн сурвалж бичиг. Эмхтгэн тайлбарласан Бадай, АлтанОргил, Эрдэнэ. - Хөххот: Өвөр Монгольнн соёльн хэвлэлийн хороо, 1985, m. 240. 
1650-иад оноос хойш Орос улс, тэр дундаа торгуудуудтай харилцаж байсан Астраханий захирагч тэднийг өргөсөн тангарагтаа үнэнч бус байгаа шалтгааныг олохоор Торгуудын тангаргийн ёсыг судалж эхэлжээ. Түүнд олзны торгууд “тэдний (манай-Н.Б.) ёсонд нохой зүсэх, андгайн үгтэйгээр бууны ам долоох нь тийм хатуу чанга зүйл биш байсан, харин хожим тэд (бид-Н.Б.) андгайн үгтэйгээр бурханд мөргөх тангарагтай, тэдний (манай-Н.Б.) ёсонд түүнээс илүү хатуу тангараг байхгүй” гэжээ. ${ }^{12}$ Үүний дүнд Астраханий захирагч ойрадуудыг бурхны шашны зан үйлээр тангараг өргөдөг болохыг мэдэж авчээ. Тэрээр Торгуудын Дайчин тайшаас бурхны шуумал дүр нэхэн авсан байдаг. Тэр үеэс торгуудууд Орос улсад өмнө өргөж байсан бөөгийн уламжлалт ба бурхны шашны зан үйлийг хослуулан тангараг өргөх болжээ. Тод бичгийн сурвалжид орос сурвалжийн

\section{ДҮГНЭЛТ}

Дээрхээс үзвэл ойрадуудад олон улсын харилцаанд тангараг өргөх өөрийн өвөрмөц зан үйл байжээ. Уг тангаргийн зан үйл Ойрад монголчуудын шүтлэг бишрэлтэй холбоотойгоор хувьсан өөрчлөгдөж мэдээтэй адил зүйлийг тэмдэглэсэн байдаг нь торгуудууд уг зан үйлээр Орос улсад тангараг өргөж байсан нь баттай болохыг харуулна. “Торгууд хаадын тууж”-д “... Андгайр тавихад Пунцаг бурханд мөргөөд шүтээн судар эрхи үнсэж, хутгаа долоогоод хоолойдоо хүргэж андгайлсан" гэжээ. ${ }^{13}$ Тэр үед нохой зүсэж цус гаргах ёс орхигдсон бололтой. Энэ нь бурхны шашны сургаалтай холбоотойгоор орхигдсон байж болох талтай юм.

Хутга, сэлэм, бууны ам долоох, бурханд мөргөх ёс нь тангаргаа зөрчсөнд тохиолдолд оногдуулах хариуцлагыг илэрхийлж буй юм. Өөрөөр хэлбэл, амласан амлалтандаа хүрэхгүй, түүнийг зөрчвөл амийг нь хөнөөнө гэсэн утгатай.

Тухайн үед суугуул нутагтаа байсан ойрадуудын Орос улсад өргөсөн тангаргийн зан үйлийн талаарх мэдээ ховор юм.

иржээ. Ойрадууд бурхны шашныг шүтэх болсоноор яваандаа мал, амьтан алж тангараг өргөх бөөгийн ёсны үлдэгдэл үгүй болсон байна.

12. В.Т.Тепкеев. Калмыки в Северном Прикаспии во второй трети ХVII века. - Элиста, 2012, с. 193-194.

13. Торгууд хаадын тууж. - Ойрад түүхэн сурвалж бичиг. Эмхтгэн тайлбарласан Бадай, Алтан-Оргил, Эрдэнэ. - Хөххот: Өвөр Монгольнн соёлын хэвлэлийн хороо, 1985, m. 334. 


\section{OATS CUSTOM OF OIRAT MONGOLS OF THE $17^{\text {th }}$ CENTURY}

N. Bayartsetseg

Mongolian State University of Education E-mail: o_erdeneus@yahoo.com

This article dealing with the oath custums of oirat mongols of the 17th century in their relationship with Russian Tsar'. The study of customs is essential for the revealing the aims and contents of those oaths made by Oirat princes toward Russia.

From the beginning of 17th century number of Oirat envoys of were sent periodlically to Siberian towns and sometimes directly to Moscow to take an oath of allegiance to the Tsar' of Russia. The true reason of these acts was far more different of the appearance; it is wrong that they were took the oaths with sincerety, but considered it as a mean to resolve tactical issues. Those in fact was a diplomatic cover of implicit competition of the obvious adversaries for the control over South Siberia - Tsarist Moscovia and Oirat Princes.

According to detailed analysis of written sources we could unveil two layers of oarh customs : 1) more traditional related to the shamanistic rites, such as cutting the dog, licking the edge of knife or hole gauge; 2) newly coming rites related with the Buddism, like to pray to Buddha. This attest the evolution of the customs of oirats during their way of adopting ther Buddism, mainly forbiding of blood rites. 